NBER WORKING PAPER SERIES

\title{
ORPHAN DRUG DESIGNATIONS AS VALUABLE INTANGIBLE ASSETS FOR IPO INVESTORS IN PHARMA-BIOTECH COMPANIES.
}

\author{
Philippe Gorry \\ Diego Useche \\ Working Paper 24021 \\ http://www.nber.org/papers/w24021 \\ NATIONAL BUREAU OF ECONOMIC RESEARCH \\ 1050 Massachusetts Avenue \\ Cambridge, MA 02138 \\ November 2017
}

We thank colleagues of GREThA, especially Francesco Lissoni, and conferences participants at DRUID2016 and NBER PPMf2017 conferences for helpful comments. This work was supported by a grant on "Rare Cancers \& Orphan Drugs, innovation and Inequality" from INCa (\#9580) to PG, and a Post-Doctoral Fellowship to DU from the French State in the frame of the "Investments for the Future" program IdEx Bordeaux (ANR-10-IDEX-03-02). The authors declare no conflict of interest. The views expressed herein are those of the authors and do not necessarily reflect the views of the National Bureau of Economic Research.

At least one co-author has disclosed a financial relationship of potential relevance for this research. Further information is available online at http://www.nber.org/papers/w24021.ack

NBER working papers are circulated for discussion and comment purposes. They have not been peer-reviewed or been subject to the review by the NBER Board of Directors that accompanies official NBER publications.

(C) 2017 by Philippe Gorry and Diego Useche. All rights reserved. Short sections of text, not to exceed two paragraphs, may be quoted without explicit permission provided that full credit, including $(\odot$ notice, is given to the source. 
Orphan Drug Designations as Valuable Intangible Assets for IPO Investors in Pharma-Biotech Companies.

Philippe Gorry and Diego Useche

NBER Working Paper No. 24021

November 2017

JEL No. G11,G24,I1,L65,O32,O34

\begin{abstract}
Orphan Drug (OD) legislation has been implemented with regulatory and financial incentives to encourage drug innovation in order to treat rare diseases. This study aims to test whether OD Designations (ODD) granted by the Food and Drug Administration (FDA) to pharmaceutical and biotechnology start-up companies may be considered as relevant signals in attracting entrepreneurial finance and increasing the amount invested at the time of the Initial Public Offering (IPO) in the US stock markets. We found that the signaling power of ODD is positively and statistically significant for IPO investors in stock markets. Regression results also suggest that ODDs are stronger than patent applications in attracting IPO investors. Scholarly and policy implications are discussed in the light of the signaling theory and drug development policies.
\end{abstract}

\author{
Philippe Gorry \\ GREThA UMR CNRS 5113, \\ Université de Bordeaux \\ Ave Leon Duguit \\ 33608 Pessac FRANCE \\ philippe.gorry@u-bordeaux.fr \\ Diego Useche \\ CREM-CNRS Faculté des Sciences Économiques \\ University of Rennes 1 \\ 7, Place Hoche CS 86514 \\ 35065 Rennes Cedex \\ France \\ diego.useche@univ-rennes1.fr
}




\section{INTRODUCTION}

Drug development is characterized by a long development cycle (between eight and twelve years on average) and a high attrition rate, especially between preclinical and clinical phases. Therefore, investment in pharmaceutical product development is highly risky because it involves substantial costs to develop a product candidate that may fail to obtain regulatory approval or to become commercially viable. Return on investment in the pharma-biotech sector depends heavily on patent protection for new drugs in order to provide a period of market exclusivity. Over the last few decades, the productivity of pharmaceutical companies measured by the number of new molecular entities has been steadily declining (Paul et al., 2010). A critical question to understand how the biotech sector operates has been called the "Pisano puzzle": Why would money from investors flow into an industry in which profits are so hard to come by? (Pisano, 2006). In the case of rare disease drug development, the question is even more relevant as sponsors are additionally confronted with a problem of low demand (Rzakhnov, 2006; Yin, 2008). Many biotech and rare disease drug sponsor companies have devoted impressive financial resources to Research and Development (R\&D), including non-clinical development activities and clinical trials, while at the same time they are not generating revenues and cannot estimate with precision the extent of their future losses (Pisano, 2006; Rzakhnov, 2006; Yin, 2008; Lazonick, 2011)

For pharma-biotech start-ups the capacity to raise money through global pharmaceutical company partners, Venture Capitalists (VC) and IPO investors is a fundamental factor for drug innovation and orphan drug development. In contrast, investors in high-tech firms have become more cautious over the last decade and have delayed their investments until firms demonstrate more tangible research outputs (Pisano, 2006). Investors in biotech start-up companies are increasingly risk-averse and have become more cautious in selecting firms with a high growth potential, as they are usually young, unprofitable, and niche market oriented. These investors tend to measure investment potential by analyzing considerable data gathered on firms' histories and their perceived market potential. Thus, the companies intending to go public have to convince evaluators that it is worth investing in them (Wilbon, 1999; Useche, 2014). The case of Aegerion Pharmaceuticals illustrates the difficulty to evaluate young Orphan Drug developers. The company was founded in 2005 to develop novel therapeutics to treat rare genetic lipid disorders. As many development stage companies, Aegerion founded its operations through private placement of stocks, convertible debt 
GORRY-USECHE NBER PPMf2017

and venture debt while it was not generating revenue and its accumulated deficit rose \$74.6 million in 2010. The company decides to go public after having started expensive Phase III clinical trials for its pivotal compound lomitapide in 2010. At that time, the company has filed for only 4 patents which is largely lower that the number of patent applications of rare diseases sponsors at the time of their IPO (on average 15 applications). In contrast, Aegerion was very active searching for regulatory approval and support and 3 Orphan Drug Designations were already applied at the FDA Office of Orphan Products Development.

In this paper, we aim to test whether Orphan Drugs Designations (ODD) applied prior to an IPO may be considered as a valuable intangible asset which influence the way investors perceive biotech firms' potential through an increase in the amount invested at the time of the IPO in the United States (US) of America stock markets. The literature has highlighted the value and the nature of different technology and organizational characteristics that may be considered as signals for IPO investors in high-tech companies. As organizational signals, the literature stresses, for example, the influence of venture capital (Lerner, 1994; Gompers, 1995), strategic alliances and inter-organizational networks (Stuart \& al., 1999), the firm's underwriter supporting the IPO firm (Loughran and Ritter, 2004), and any other signals that may help reduce asymmetric information and improve IPO performance. The managerial and innovation literature has also analyzed some technology characteristics as patents and drug portfolio which helps to reduce uncertainty and skepticism regarding an IPO firm's performance (Long, 2002; Guo et al., 2005; Mann, 2005; Heeley, Matusik and Jain, 2007; Hsu \& Ziedonis, 2008; Useche, 2014). We show that ODD convey a powerful certification and reputational component which attack IPO investors. ODD appears even to be more relevant than other technology characteristics as patents applications or later stage drugs compounds to attract IPO investors. Those results are particularly important in a context steadily declining of new molecules and strong market imperfections to assure R\&D investments in rare diseases drugs.

The remainder of this paper is as follows. Section 2 reviews the literature on the anatomy of the rare disease drug development market and the emergence of Orphan Drug Designations (subsection 2.1) and set out the main characteristics, which makes ODD valuable intangible assets and technology market signals for investors in biotech companies (subsection 2.2). Section 3 discusses the methodology and data. Regression results, alternative models, and robustness checks 
GORRY-USECHE NBER PPMf2017

are provided in Section 4. A discussion on the main results and the conclusions are presented in Section 5.

\section{BACKGROUND}

\subsection{Orphan Drug legislation and the rare disease drug development market: a review.}

The biotechnology and pharmaceutical industries are characterized by highly uncertain technology development, intense competition and a strong emphasis on intellectual property. The development of biotech drugs is a long and risky process in which it can take 10-20 years to yield a commercial product with highly uncertain prospects for success (Lazonick, 2011). According to the literature (Pisano, 2006; Hay et al., 2014), it is estimated that only one out of about 6,000 synthesized compounds has ever made it to market, and only $10 \%$ to $20 \%$ of drug candidates beginning clinical trials have ultimately been approved for commercial sale. Drug development for rare diseases is confronted with profound and persistent uncertainty and long-term risks that are remarkably costly in relation to a small number of consumers (Rzakhnov, 2006; Yin, 2008). According to Moors and Faber (2007), orphan drug development is particularly complex and risky because the disease lacks a knowledge base and patient groups for clinical trials are small. Therefore, OD development requires more collaboration with other stakeholders than conventional drug development (Moors and Faber, 2007).

The anatomy of the orphan drug industry, which is mainly composed of biotech firms, is structured by strong intellectual property rights driving the feasibility and direction of technology development, the market for know-how and finally access to funding and R\&D alliances. Orphan Drug sponsors mainly rely on four sources of funding to develop new drugs: (i) R\&D government grants, (ii) venture capital investments, (iii) public equity markets and (iv) strategic alliances (Pisano, 2006). VC investments and, in most cases, R\&D alliances involve a capital injection into the startup giving the venture capitalist or the established company an equity stake (Lazonick, 2001). Biotech startups depend heavily on $R \& D$ alliances, which usually include an $R \& D$ contract from the established company for the young firm to engage in drug development in exchange for intellectual property rights and marketing rights when the drug is approved (Lazonick, 2011).

Orphan drug sponsors, as well as other biopharmaceutical companies, still find it extremely difficult to predict how a particular new molecule will be safe and efficient in humans. Sometimes, intellectual property rights may not provide sufficient incentive for drug $\mathrm{R} \& \mathrm{D}$. Markets for new drugs 
may be too small for firms to operate (Rzakhnov, 2006). Over the last few decades, advances in the biotechnology industry have increased pathophysiological knowledge of diseases, the number of molecular targets to attack them, and novel approaches for cures (Pisano, 2006). Until late in the 1970s drugs with potential benefits to rare disease populations were "orphaned" (Rohde, 2000). This evidence motivated lobbying effort, from patient groups frustrated at the lack of drugs approved to treat rare diseases, to pass orphan drug legislation (Yin, 2008). In order to stimulate innovation in rare disease drugs, the Orphan Drug Act (ODA) was adopted on January $4^{\text {th }}$ 1983. It was the first regulation adopted in the world to offer incentives for drug development for rare diseases on the basis of supply-side incentives. The ODA was enacted to stimulate the development and marketing of orphan drugs which are a particular kind of highly risky-development drugs used to treat rare diseases and conditions (Seoane-Vasquez et al., 2008; Garden et al., 2017¹). Indeed, before the ODA, only a small number of rare disease treatments were authorized by the FDA (Asbury, 1991; Seoane-Vasquez et al., 2008). After the ODA, orphan drug R\&D became increasingly dynamic and more than 400 orphan treatments have been approved (Seoane-Vasquez et al., 2008; Garden et al., 2017). This spectacular turnaround proves that pharmaceutical companies no longer disregard rare diseases. In fact, OD research today appears to be one of the most dynamic business segments of the pharmaceutical industry (Figure 1).

While the previous literature has shown that ODD had a significant impact on rare disease drug development, little is known about how ODDs may help orphan drug sponsor firms to attract investors, and in reducing problems of asymmetric information and risk.

\subsection{Hypothesis: OD designations as valuable intangible assets and market signals}

OD designations may be considered as valuable intangible assets which may attract investors in pharma-biotech start-up companies. Similarly to patent applications, OD designations may be considered as signals because they are a readily observed attribute correlated with company performance and market strategy (Long, 2002; Mann, 2005; Heeley, Matusik and Jain, 2007; Hsu \& Ziedonis, 2008; Useche, 2014; Hoenig and Henkel, 2015). OD designations can represent a signal of the quality of a start-up's technology according to the signaling theory of Spence (1973). In order to be effective, signals need to be observable and costly (Spence, 1973; Long, 2002; Hsu \& Ziedonis, 2008; Useche, 2014). Observability describes the extent to which outsiders are able to

\footnotetext{
${ }^{1}$ https://www.innovationpolicyplatform.org/content/health-innovation-rare-diseases.
} 
notice the signal. Since the ODD is publicly disclosed by the FDA as a regulatory agency, the ODD signal is directly observable by outsiders. The comprehensive examination by the FDA Office of Orphan Drug Products Development works as a certification mechanism, and might parallel the signaling power of patents (Heonig and Henkel, 2015). Investors will surely interpret Orphan Drug designations as a positive sign of the innovative capacity of the companies in question, in a market characterized by an astonishing pipeline of new innovative drugs developed by the major pharmaceutical companies in the past decades (Paul et al, 2010).

ODDs are also costly to obtain and they provide a selection mechanism which allows observers to distinguish among different qualities and firm strategies. Even though sponsor firms granted ODDs by the FDA are exempted from the prescription drug user fee, drug development for rare diseases is particularly costly, complex and risky because the diseases lack a knowledge base and patient groups for clinical trials are small (Rzakhnov, 2006; Yin, 2008). In order to compensate and stimulate to some extent rare drug developers, Orphan Drug Designations offer several advantages which may suggest that the holder has a competitive advantage and offer a sign of their higher quality and technology compared to other companies. First, an OD Designation holder has an exclusive right, and may sell at an unregulated price over the 7-year period without competition. This monopoly starts at market approval date and is independent of intellectual property rights. Second, a subsequent innovator that develops a new drug prior to expiration of the exclusivity right can replace the incumbent only if the new drug is "clinically superior" to the "old" drug on the market. This expiration of exclusivity does not call into question any intellectual property rights linked to the orphan drug. Third, for the drug sponsors the OD Designation provides a 50\% tax credit on the clinic trial cost, a fee waiver for regulatory activities, and some assistance from the Office of Orphan Products Development. Fourth, the FDA's exclusive marketing right can effectively be transferable to another company subject to the consent of the regulator. Fifth, an orphan designation and exclusive marketing right cannot be revoked later if the drug proves to have greater commercial potential, and is therefore considered as a real option. In addition, Orphan drugs have shorter development time than other drugs (Seoane-Vasquez et al., 2008).

In addition, ODD offers also powerful certification and reputational value. Moors and Faber (2007) suggest that ODDs may provide a powerful incentive for image improvement for finance seeking start-ups in orphan segments with a lack of profound knowledge base. The certification component of ODDs may also help orphan drug sponsors to find valuable external resources, such 
GORRY-USECHE NBER PPMf2017

as competent R\&D partners and valuable employees to hire. The 'legal certification' component of Orphan Drug Designations is assured by the FDA Office of Orphan Products Development (OOPD), which receives, reviews and eventually approves Orphan Drug requests. The main criterion to obtain an ODD is to develop drugs to treat rare diseases defined as those affecting less than 200,000 patients in the US or those drugs for which R\&D investment would not be recovered by product sales. In addition, the Orphan Drug Amendment of 1988 allows sponsors to request an ODD for any unapproved use of a drug without regard to whether other indications of the drug were approved previously for marketing. The 'legal certification' component of OD Designations may also facilitate access to contracts, grants or subsidies, potentially increasing future firm performance. As such, it supports the appropriation of returns from innovation and facilitates cooperation with business partners.

For these reasons, Rzakhanov (2008) suggests that OD designations may have similar characteristics to patent design and may be considered as a valuable intangible asset for their holder. However, Orphan Drug exclusivity offers the second broadest level of protection because the provision protects the Orphan designated indication against generic and full NDA approval (SeoaneVasquez et al., 2008). It should be pointed out that market exclusivity is a post-approval incentive that begins on the date of the FDA market approval for the designated orphan indication. Policies on OD development operate within the FDA regulation framework: sponsors need first to file an Investigational New Drug (IND) before initiating clinical studies, and later on a New Drug Application (NDA) or a Biologics License Application (BLA). It is important to note that sponsors of ODs frequently qualify for fast-track status accelerated approval and priority review under the Prescription Drug User Fee Act of 1992 (Shulman and Manocchia, 1997; Seoane-Vasquez et al., 2008). As a matter of practice, drug regulatory requirements might be more relaxed for rare diseases at the discretion of the FDA, and ODs are likely to qualify for lower approval standards (Kesselheim, 2011).

The literature on OD designations has found that ODs may be associated with higher firm performance. Rzakhanov (2008) reports that both OD designation and market approved OD are associated with higher market value for firms, but to a lesser extent than non-orphan drugs. His work was based on a heterogeneous sample of OD sponsor firms $(n=60)$ and biotech firms without OD under development gathered before 2000, and covering the entire spectrum of firms: from spinoffs to public companies. 
However, there is little evidence on how Biotech IPO subscribers use OD Designations as a credible signal of high firm value, competitive advantage and future firm performance on financial markets. We aim to study how ODDs may influence IPO investors through a higher amount of cash invested at IPOs, other factors remaining fixed. To address these issues, we perform econometric regressions on the relationship between various metrics of firm quality contained in patents prior to the IPO and the amount of cash collected at the IPO, while controlling for other factors that may influence IPO performance (Ritter and Welch, 2002; Brau and Fawcett 2006).

\section{DATA AND MEASURES}

\subsection{Data sources}

We built an original database linking data from 5 different sources: i) the IPO prospectuses and S-1 registration statement database, ii) FDA Orphan Drug product designation database, iii) Orbit ${ }^{\circledR}$ patent database (owned by Questel), iv) the Pharmaproject ${ }^{\circledR}$ (owned by Citeline) for the drug pipeline and v) VentureSource ${ }^{\circledR}$ (owned by Dow Jones) for corporate and VC investment before IPO. IPO prospectus and forms S-1 were retrieved from different sources: the NASDAQ website, US Securities and Exchange Commission (SEC) archives and the EdgarOnline ${ }^{\circledR}$ database provider for historical data with financial, ownership and shareholder information. The FDA Office of Orphan Drug Products (OOPD) maintains an OD designations and approvals database, where OD statuses are logged in, with product and designation information, as well sponsor information. The patent analysis was run in the worldwide collection of INPADOC (International Patent Documentation; EPO worldwide legal status database) family patents using the Orbit ${ }^{\circledR}$ patent research platform which provides an applicant search function based on company structure using FactSet $^{\circledR}$ corporate tree data. (Useche, 2014). ${ }^{2}$ Pharmaproject $^{\circledR}$ is a proprietary data source including drugs developed in pharmaceutical markets worldwide from 1980 to date and has been used in pharmaceutical industry economics research (Hirai et al., 2012; and references therein). Finally, VentureSource ${ }^{\circledR}$ is a global database on companies backed by venture capital and private equity in every region, industry and stage of development and was used to retrieve details about

\footnotetext{
${ }^{2}$ Questel-Orbit is a patent database which allows the users to build and organize patent portfolios and examine individual patents. The QPAT database has developed a family definition (FamPat family) which provides comprehensive family coverage of worldwide patent publications.
} 
rounds of financing ${ }^{3}$.

\subsection{Sample description}

Our approach to building the dataset was to identify IPO deals concerning Orphan Drug designation applicant firms from the United States, between January $1^{\text {st }} 1995$ and December $31^{\text {st }}$ 2015. Our primary data source was the FDA Orphan Drug Product designation database. From 1983 to December 2015, more than 3000 OD were registered by some 1400 sponsors worldwide (including firms, universities, physicians, patient advocacy groups and other non-profit organizations). The OD designation trend accelerated from the year 2000 following several provisions implemented by the U.S. congress: Rare Diseases Act (2002), OOPD, Medicare Patient Access Drugs for Rare Diseases Act (2003) (Figure 1). All OD designation sponsor firms obtained were cross-referenced with firms that were listed, or had been listed, either on the New York Stock Exchange (NYSE) or on the National Association of Securities Dealers Automated Quotations (NASDAQ). We identified 277 firms applying for Orphan Drug designations which had been traded on NYSE or NASDAQ. Next, we tracked all the OD applicants that had gone public since 1983 and collected IPO information primarily from the final IPO prospectuses and S-1 registration filings issued when those firms went public $(n=253)$. Trends of IPOs with OD portfolios does not parallel the OD designation trends, and the acceleration of IPOs of OD firms is recent, except for a peak of IPOs around the dot-com bubble in 2000 (Figure 2). Considering only those companies with available information about pre-IPO characteristics and the amount of cash collected at IPO, our final sample is composed of 146 OD IPO firms between January $1^{\text {st }} 1995$ and December $31^{\text {st }} 2015$. These companies are mostly quoted on the NASDAQ (98\%) and are US firms (92\%). Most of these firms are drug companies operating in the pharmaceutical (73\%), diagnostic or biotechnology (18\%) sectors, and are considered Pharma-Biotech companies (93\%) according to the SIC codes (Table 1). In that respect, our sample differs from the ones described by Higgins et al (2011) (they excluded SIC\#2833) and is closer to the sample of Guo et al (2005), except for one firm classified in the "surgical \& medical instruments \& apparatus" category. It is important to note that of the firms we included, none are classified as "big pharma”, i.e., companies ranked in the top 50 by annual revenue. 


\subsection{Measures}

\subsubsection{Value- IPO proceeds as dependent variable}

We are interested in how Orphan Drug sponsors use OD designations obtained prior to IPOs as a credible signal of high firm value and competitive advantage and to determine the future firm's performance on financial markets. We followed the literature and used traditional measures of performance which were mainly collected through the IPO prospectuses and S-1 registration filings database. Traditional measures of IPO performance are based on the amount of cash collected by the firm at the IPO (Chemmanur and Fulghieri, 1994; Ritter and Welch, 2002; Higgins et al., 2011), the pre-money valuation of the firm (Stuart et al., 1999; Higgins and Gulati, 2003), and the age of the venture at the IPO (Chang, 2004). We chose as our key dependent variable PROCEEDS, the amount of cash collected by the firm i at the IPO date $(t)$. This measure of IPO performance avoids potential problems of over allocation in the pre-money valuation (Ritter and Welch, 2002; Higgins et al., 2011). A log-transformed variable of PROCEEDS was used to address the valuation data skew and reduce its heterogeneity.

\subsubsection{FDA Orphan Drug designation portfolio as independent variable}

OD designations may have similar characteristics to patent designs. They are intangible assets of firms and a source of potential revenue streams, which are however not listed explicitly on a company's balance sheet. As objects of intellectual capital, they could be transferred to third parties under the law (licensing, merger and acquisition, bankruptcy). As claimed before, among other advantages, OD designation provides drug sponsors with a 50\% tax credit for clinical trial costs, a fee waiver for regulatory activities, fast-track evaluation for market approval and some assistance from the Office of Orphan Products Development. 


\subsection{Control variables}

\subsubsection{Drug pipeline and intellectual propriety portfolio.}

Patent protection of drugs in R\&D is essential to the Pharma-Biotech industry business model in order to secure returns on large and risky investments. Therefore, we matched IPO information for each firm with the number of patents the firm filed (patents with priority date) from the Orbit database. We considered the total number of priority patent filed by the firm over the four-year period before the IPO (PATPPy4). This window in the number of patent applications was to take into account the fact that recent patents may provide the most current information about the firm's inventive capabilities at the time of the IPO (Useche, 2014).

A classical indicator of research and development in the pharmaceutical industry is the number of drugs in development, otherwise known as the "drug pipeline". We identified in the Pharmaproject ${ }^{\circledR}$ database the number of drugs under active R\&D prior to the IPO (DRUGPIPEPRIORIPO). It has been estimated that only $10 \%$ of identified molecules might make the transition to candidate and enter clinical trials (Hughes et al, 2010). So for each firm, we computed the number of compounds under active development that successfully reached the stage of clinical trial phase II (PHASE2PRIORIPO). We chose this stage indicator because it is pivotal in the drug development cycle: phase II addresses therapeutic effectiveness, it has an average time-to-market of five years (Paul et al., 2010), and the phase I stage is not discriminatory, with a 66\% success ratio (Hay et al., 2014).

\subsubsection{Age, collaborative revenues and $R \& D$ investments at IPO}

Previous research has shown that experienced entrepreneurs are more likely to be able to secure financial resources and go public (Gompers, 1995). From IPO prospectuses and the S-1 registration filings database, we collected data to control for the age of the company at IPO (AGEATIPO), which is calculated as the difference between the effective date of the IPO and the date of incorporation. In addition, we also controlled for the amount of Research \& Development expenses and the total collaborative revenues over the year before the IPO. 


\subsubsection{Venture capital and corporate venture capital support}

We collected information related to venture capital support using the Venture Source database. Venture Capital support usually provides a sign of confidence about the firm's management, technology and capabilities (Megginson and Weiss, 1991; Gompers, 1995, Brau and Fawcett, 2006). For these reasons, we included the dummy variable VENTUREBACKED which indicates whether the IPO was backed by one or more venture capital firms, and the dummy CORPVCAP which is equal to one if the IPO was backed by one or more Corporate Venture Capitalists (CVC) and zero otherwise. We also introduced the number of venture capital rounds before the IPO (VCROUND), the variable VCINTENSITY which is defined as the number of years between the first VC investment and the IPO date, and the variable VCFUND defined as the amount of money collected from Venture Capitalists prior to the IPO. It is expected that venture backed companies produce a greater IPO performance than ventures quoted without similar funding support

\subsubsection{Percentage of the firm being sold and underwriter reputation}

We followed the literature (Leland and Pyle, 1976; Brau and Fawcett, 2006; Higgins \& al., 2011; Carter and Manaster, 1990) and controlled for the percentage of the firm to be sold during the public offering and for underwriter reputation. The literature has shown that the market should consider the sale of a large portion of the company as a negative sign. Indeed, a large share of the company being sold may signal that the current owners have negative inside information on the company. Then, like Higgins \& al., (2011), we included a log of the percentage of total shares of the firm that are sold (PERCENT SOLD). IPO performance is also related to underwriter reputation (Carter and Manaster, 1990). Underwriter reputation (UWREPUT) was measured with Loughran and Ritter's update (2004) of the underwriter reputation rankings developed by Carter and Manaster (1990). The lead underwriter was matched by name with the ranking score in Jay Ritter's database. ${ }^{4}$

\footnotetext{
${ }^{4}$ Underwriter ranking data available from Shane Corwin’s website http://www3.nd.edu/ scorwin/
} 


\subsubsection{Market conditions}

Finally, we used temporal, country and stock market differences in IPO deals. It has been documented that IPOs tend to come in waves, characterized by periods of hot and cold markets. First, we introduced a dummy variable coded 1 if the companies were quoted on the NASDAQ (US). We included the variable BIO_RATIO, which is the ratio defined as the number of Biotech IPOs divided by the total number of IPOs in a given year (Higgins, M.J. et al., 2011). Finally, we controlled for the dot-com bubble in 1999 and 2000, years known to have impacted the life science industry. It has been demonstrated in the literature that firms raised more cash from the NASDAQ stock market during this hot issue period (Chok and Qian, 2013).

\subsection{Summary Statistics}

We present the description of variables and report descriptive statistics for the pharma-biotech companies sponsoring Orphan Drugs in Table 2. Some characteristics of OD sponsors prior to IPOs should be pointed out. First, it appears that about $49.31 \%$ of the companies have applied for ODDs before the IPO. It also appears that, on average, OD sponsors applied for their first ODD 2.8 years before the IPO. In contrast, most of the companies going public applied for patents four years before the IPO (89.72\%), and have a drug pipeline of 9.2 compounds on average at the time of the IPO, with only a minority of firms succeeding in pushing drug candidates into phase II clinical trial (38\%). OD sponsor companies are R\&D intensive firms spending on average of \$13.05 million while their revenue is on average $\$ 7.58$ million prior to their offering. OD firms have been supported by venture capitalists (73.2\%) at least through 2 rounds of investment for 4-5 years prior to the IPO. The average amount raised by the IPO (based on proceeds) was $\$ 60.04$ million.

As a preliminary examination of the univariate relationships among the variables in the present study, Pearson correlation coefficients were estimated. Table 3 shows the results of these estimations for each of the variables. The analysis indicates that several of the variables are positively correlated to one another, and many of the findings reported in earlier research are evident in the values found. For example, proceeds from IPOs are strongly correlated with R\&D expenses. As one might expect, IPO proceeds are also correlated with the presence of venture capitalist. Moreover, the number of patent applied four year before IPO are correlated with R\&D expenses and the former is also correlated with VC investments. 


\section{ECONOMETRIC STRATEGY}

\subsection{The main model}

We use the following model to test our hypotheses.

$$
\log (I P O P R O C E E D S)_{i t}=\alpha_{i t}+\Upsilon_{i t} O D D_{i t}+\beta_{i t} X_{i t}+\theta_{i t} Y_{i t}+w_{i t}(\mathbf{1})
$$

We aim to test the impact of Orphan Drugs Designations (ODD) on IPO performance measured by the logarithm of the amount of cash collected by the firm i at the IPO date i (PROCEEDS). We follow the literature (Leland and Pyle, 1976; Megginson and Weiss, 1991; Ritter and Welch, 2002; Brau and Fawcett, 2006; Higgins et al., 2011) and control for variables that have been associated with IPO valuation $\left(Y_{i t}\right)$. We included a dummy variable (UWREP) taking the value one if the underwriter reputation ranking proposed by Loughran and Ritter (2004) is equal to or greater than 8.00, and zero otherwise. We followed the literature (Leland and Pyle, 1976; Brau and Fawcett, 2006; Higgins \& al., 2011) and controlled for the percentage to be sold during public offering (PERCENT SOLD) and two market conditions controls (BIO_RATIO) (Higgins \& al., 2011) and Bubble (Chok and Qian, 2013). We also included the variable VENTURE_BACKED taking the value one if the company has been supporter by at least one venture capitalists, zero otherwise (Megginson and Weiss, 1991; Gompers, 1995; Brau and Fawcett, 2006). Finally, we also included a set of firm-related characteristics, which may influence IPO performance measured on the previous year at IPO $\left(X_{i}\right)$. We included the logarithm of the total amount of collaborative revenues (REVENUES) and the R\&D expenses (R\&D_EXPENSES) on the previous year to IPO. In addition, we also include the age of the company (AGE AT IPO) and the number of employees (EMPLOYEES) at the time of the IPO. Finally, we included a dummy variable coded one if the company’s principal segment sector is pharmaceutical preparations (USSIC2834).

We followed the literature and attempted to account for the endogeneity of Orphan Drug Designations at IPO. Endogeneity arises if unobserved firm characteristics affecting the decision to apply for OD designations may also influence IPO pricing. Some of these variables which are not observable, such as specific firm characteristics and management quality are included in the error 
terms in $w_{i}$ in Eq. (1). The correlation between the error term and our variable of interest ODD will result in endogeneity. We tried to deal with endogeneity by way of a generalized method of moment (GMM) estimator. In our choice of instruments, we choose the number of years between the first Orphan drug application and the IPO date (OD_EXPERIENCE). Greater experience with the FDA Office of Orphan Drug Products Development may facilitate future applications. In contrast, there is no reason to think that IPO investors have the capacity to determine the number of years from the first Orphan drug application to IPO. In addition, we introduced the variable ODLAGGEDT4 which is the number of OD designations lagged four years before the date of the IPO. Here, we followed Anderson and Hsiao (1981) who used lagged variables as instruments for themselves (see also: Baltagi and Khanti-Akom, 1990; Windmeijer, 2005).

\subsection{Results}

Table 4 reports the results of our two estimation procedures for the main model (Eq.1): OLS regression (Model 1) and second stage of GMM estimator (Model 2). We observe that there is little variation across OLS and GMM regressions. Estimations results suggest that an additional ODD before IPO is related with an increase of about $18.3 \%$ and $17.3 \%$ in proceeds collected by companies at IPO, from OLS and GMM estimates respectively. Several tests presented at the bottom of the table (Model 2) validate our instrumental variable approach and fails to regret the exogeneity of $\mathrm{ODD}^{5}$. Based on the coefficient $O D D(0.183)$ for US biotech IPOs deals and based on the fact that the median value of cash collected at IPO is around \$60.04 million in the US stock markets, we can infer that an Orphan drug sponsors may raise around \$10.98 million, for an additional OD designation prior to an IPO, holding other factors fixed.

Results from OLS model also confirm the positive certification role of venture capitalists and underwriter reputation for IPO investors. Results also suggest that larger companies in terms of number of employees and R\&D expenses have higher IPO valuations. In contrast, the age of the company at IPO is negatively related with larger amounts of cash at IPO. As expected, market conditions also strongly influence the IPO proceeds. Notice that the coefficients of the number of

\footnotetext{
${ }^{5}$ Tests of over-identifying restrictions, presented at the bottom of the table, fails to reject the exogeneity of the instruments with Sargan statistics (0.501, p-value 0.479) that confirms the validity of the instruments. In addition, the instruments' relevance condition is satisfied because the instruments are statistically related with the number of ODD before IPO at the $5 \%$ and $1 \%$ level, respectively. First stage regressions are available upon request. In checking for the weakness of the instruments we find that F-statistics of 130.7 that largely exceeds the critical value of 19.93 for GMM with $10 \%$ level of relative bias. Then, we firmly reject the null hypothesis of weak instruments.
} 
patent applied before IPO with a four-year window (PATAPPy4) and the number of Drugs in at least Phase II in the Pipeline prior to IPO (PHASE2PRIORIPO) are positive but not statistically significant.

\subsection{Alternative and Robustness checks models}

In the robustness checks presented in table 5, we performed OLS and limited information estimator (LIML) regressions with alternative model specifications to test the stability of our coefficients. LIML estimator is an alternative estimator asymptotically equivalent to GMM but with better finite-sample properties. In models 3 and 6, we used the total number of Drug in the companies' pipeline prior to IPO instead of the number of Drugs in at least Phase II in the Pipeline prior to IPO. In models 4 and 7, we also introduced the logarithm of the amount of cash collected from venture capitalist prior to IPO (LOG(VCFUNDS+1)) instead of a dummy variable VENTURE_BACKED. Here, we aimed to consider differences in the intensity of Venture Capital support prior to IPO. Finally, in models 5 and 8 we added simultaneously the number of Drugs in at least Phase II and all the other Drug under development by the firm at the time of the IPO. Regression results suggest that increases in the intensity of VC support also influence the amount of cash collected at IPO. In contrast, different measures of the Drug Pipeline developed are not statistically significant for IPO investors. Considering our key explanatory variable ODD, we observe that there is little variation in the coefficients and standards errors compared with baseline model $^{6}$.

\section{DisCUSSION AND CONCLUSION}

This paper aims to look how Orphan Drug Designations operates as credible signals for IPO investors in US stock markets. To this end, we have built an original database linking data from 5 different sources: the IPO prospectuses and S-1 registration statement database, the FDA Orphan

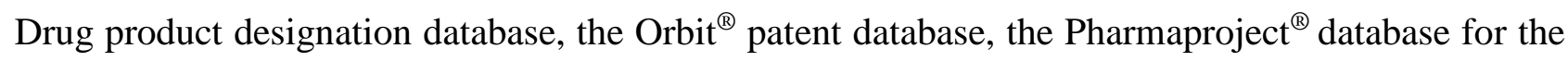
drug pipeline and VentureSource ${ }^{\circledR}$ for corporate and VC investment before the IPO.

\footnotetext{
${ }^{6}$ In robustness checks not presented here, we also introduce the total number of patents applications prior to IPO instead of the patents applied four years before IPO. Results reflect that the patent portfolio is not taken into account by biotech IPO investors. For the sake of brevity, the regressions are not included but results are available upon request.
} 
GORRY-USECHE NBER PPMf2017

We show that Orphan Drugs Designations represent a valuable intangible asset with a powerful certification and reputational component which attack IPO investors. The above-mentioned impact of ODDs on IPO financing might be explained by two main functions of an ODD for pharmabiotech start-ups: its signaling value, and its productive effects (exclusionary and/or markets for technology effects).

Since the OD Act, the FDA has granted more than 3000 OD Designations and approved more than 400 orphan drugs for marketing (Garden et al., 2017). 85\% of the Orphan Drugs have been developed by small or medium sized pharma-biotech enterprises, and half of the market-approved orphan drugs belong to the biotechnology industry (Côté, 2012). The promise of a 7-year market exclusivity and the 50\% tax credit for clinical drug testing are attractive enough for investors to balance the risk linked to targeting a niche market.

Our study has both scholarly and policy implications. Our analysis contributes to the theoretical and empirical literature on entrepreneurial finance, which has examined a number of issues related to start-up financing and patents (Conti et al., 2013). This paper address for the first time the use of Orphan Drug Designations as a signal in the context of IPO financing. This signal is particularly important for the biotech industry as the drug development process, which is expensive, lengthy and risky, depends heavily on external investment funds. Orphan Drug Designations share many properties with patents as intellectual assets: monopolistic market rights limited in time and space, quality signal, facilitating cooperative arrangements and transactional value. Indeed, we found that OD designations are more valuable than patents to attract IPO investors.

However, it remains unclear which of the market exclusivity or the tax refund is the more effective incentive measure; is market exclusivity, limiting the competition and approval of another version of the same orphan drug, the most powerful signal for investors as it secures long-term monopoly profits, or are investors more sensitive to the tax-credit, the lowering of drug R\&D costs, and the short-term balance sheet. We argue that IPO investors are more interested in the competitive advantage related to the tax credit, and not that related to market exclusivity. Otherwise the patent portfolio would be more important for IPO investors that OD designations. But a clear separation between the effects of these two incentives is not possible. 
GORRY-USECHE NBER PPMf2017 These findings also have important implications for policymakers. The OD Act with its regulation and financial incentives succeeded in attracting private investments, and represents an opportunity for biotech companies, which depend on external finance. If one could draw a parallel between rare and neglected diseases, Orphan-type legislation might provide a solution to attract investments to support drug development for tropical diseases, for example (Anderson, 2009). This type of supplyside incentive seems to be stronger in attracting external investors than patent protection. Recently the FDA implemented a new support for stimulating the development of new antibiotics, the “Generating Antibiotics Incentives Now” or GAIN7. The new law provides an additional five years of exclusivity. It remains to be seen whether this legislation will succeed in attracting biotech companies and private investors.

Despite these successes in developing orphan drugs, academic researchers and rare disease advocacy patient organizations, especially in Europe, have raised questions about the financing of drug R\&D for rare diseases. The European Commission introduced an orphan drug legislation in 2000 providing incentives for companies, such as a 10-year market exclusivity and fee waivers. Future work should explore whether ODD are also signals for the European stock markets and whether they are also more valuable that patent protection to attract investors. It could also be interesting to compare the European Union and the US in terms of the signaling value of Orphan Drug Designation for investors. Future studies should also examine more explicitly the trade-offs associated with alternative quality signals at different stages of the drug development and the relative importance of those signals (Guo et al., 2005).

\footnotetext{
${ }^{7}$ https://www.congress.gov/bill/112th-congress/house-bill/2182
} 


\section{REFERENCES}

Anderson, T. W., and C. Hsiao. 1981. Estimation of dynamic models with error components. Journal of the American Statistical Association 76: 598-606.

Anderson, G.F., 2009, Spurring New Research For Neglected Diseases, Health Affairs, 28, 1750-1759.

Asbury, C.H., 1991, The Orphan Drug Act. The first 7-years. The Journal of the American Medical Association, 265, 893-897.

Baltagi, B. H., and S. Khanti-Akom. 1990. On efficient estimation with panel data: An empirical comparison of instrumental variables. Journal of Applied Econometrics 5: 401-406.

Brau, J., and Fawcett, S., 2006, Initial Public Offerings: An Analysis of Theory and Practice. The Journal of Finance, LXI, 399-436.

Carter, R., and Manaster, S., 1990, Initial public offerings and underwriter reputation. The Journal of Finance, 45, 1045-1067.

Certo, S.T., Holmes, M.R.Jr, and Holcomb, T.R., 2007, The influence of people on the performance of IPO firms. Business Horizons, 50, 271-276.

Chang S.J., 2004, Venture capital financing, strategic alliances, and the initial public offerings of Internet startups. Journal of Business Venturing, 19, 721-41.

Chemmanur, T., and Fulghieri, P., 1994, Investment bank reputation, information production, and financial intermediation. Journal of Finance, 49, 57-79.

Chok, J., and Qian, J., 2013, Do executives' backgrounds matter to IPO investors? Evidence from the life science industry. PlosOne, 8, e60911.

Conti, A., Thursby, J. and Thursby, M.C., 2013, Patents as signals for start-up financing. NBER working paper, w19191.

Côté, A., 2012, What Is Wrong with Orphan Drug Policies? Value in Health, 15, 1185-1191.

Fernandez, J-M., Stein, R.M., and Lo, A.W., 2012, Commercialization biomedical research through securitization techniques. Nature Biotechnology, 30, 964-975.

Garden, H., Gorry, P., and Paris, V., 2017, Health Innovation for Rare Diseases. OECD (eds), Science,

Technology and Innovation Outlook 2016, Paris (France), OECD Publishing.

Gompers P.A., 1995, Optimal investment, monitoring, and the staging of venture capital. Journal of Finance, 50, 1461-90.

Guo, R-J., Lev, B., and Zhou, N., 2005, The valuation of Biotech IPOs. Journal of Accounting, Auditing and Finance, 20, 423-459.

Hay, M., Thomas, D.W., Craighead, J.L., Economides, C., and Rosenthal, J., 2014, Clinical development success rates for investigational drugs. Nature Biotechnology, 32, 40-51.

Heeley, M.B., Matusik, S.F., and Jain, N., 2007, Innovation, appropriability and the underpricing of Initial Public Offerings. Academy of Management Journal, 50, 209-225.

Higgins, M.C., and Gulati, R., 2003, Getting off to a good start: the effects of upper echelon affiliations on underwriter prestige. Organization Science, 14, 244-263.

Higgins, M.J., Stephan P.E., Thursby, J.G., 2011, Conveying quality and value in emerging industries: Start scientists and the role of signal in biotechnology. Research Policy, 40, 605-617. 
Hoenen, S., Kolympris, C., Schoenmakers, W., and Kalaitzandonakes, N., 2014, The diminishing signaling value of patents between early rounds of venture capital financing. Research Policy, 43, 956-989.

Hoenig, D., and Henkel, J., 2015, Quality signals? The role of patents, alliances, and team experience in venture capital financing. Research Policy, 44, 1049-1064.

Hsu, D., Ziedonis, R.H., 2008, Patents as Quality Signals for Entrepreneurial Ventures, Academy of Management Best Papers Proceedings.

Hughes, J.P., Rees, S., Kalindjian, S.B., Philpott, K.L., 2011, Principles of early drug discovery, British Journal of Pharmacology, 162, 1239-1249.

Jaffe, A., and Lerner, J., 2004, Innovation and Its Discontents: How Our Broken Patent System is Endangering Innovation and Progress, and What to Do About It. Princeton, NJ. Princeton University Press.

Kesselheim, A.S., Myers, J.A., and Avorn, J., 2011, Characteristics of Clinical Trials to Support Approval of Orphan vs Nonorphan Drugs for Cancer. The Journal of the American Medical Association, 305, 2320-2326.

Krinsky, I., and Rotenberg, W., 1989, The valuation of initial public offerings. Contemporary Accounting Research, 5, 501-515.

Lazonick, W., and Tulum, O., 2011, US biopharmaceutical finance and the sustainability of the biotech business model. Research Policy, 40, 1170-1187.

Leland H.E., and Pyle, D.H., 1977, Informational asymmetries, financial structure, and financial intermediation. Journal of Finance, 32, 371-387.

Lemley, M.A., 2001, Rational Ignorance at the Patent Office. Northwestern University Law Review, 95, 1495-1532.

Lerner, J., 1994, Venture capitalists and the decision to go public. Journal of Financial Economics, 35, 293316.

Levin, R. C., Klevorick, A.K., Nelson, R.R. and Winter, S.G., 1987, Appropriating the Returns from Industrial Research and Development. Brookings Papers on Economic Activity, 3, 783-832.

LiPuma, J., 2012, Internationalization and the IPO performance of new ventures. Journal of Business Research, 65, 914-921.

Long C., 2002, Patent signals. The University of Chicago Law Review, 69, 625-679.

Loughran, T., and Ritter, J., 2004, Why has IPO underpricing changed over time? Financial Management, 33, 5-37.

Mann, R., 2005, Do patents facilitate financing in the software Industry? Texas Law Review, 83, 961-1030.

Mansfield, E., Schwartz, M., and Wagner, S., 1981, Imitation costs and patents: an empirical study. Economic Journal, 91, 907-918.

Mayston, D., 2009, The Determinants of Cumulative Endogeneity Bias in Multivariate. Analysis. Journal of Multivariate Analysis, 100, 1120-1136.

Megginson, W.L., and Weiss, K.A., 1991, Venture capitalist certification in initial public offerings. Journal of Finance, 46, 879-903.

Merges, R.P., and Nelson, R.R., 1990, On the Complex Economics of Patent Scope. Columbia Law Review, 90, 839-916.

Moors, E.H.M., and Faber, J., 2007, Orphan drugs: Unmet societal need for non-profitable privately supplied new products. Research Policy, 36, 336-354. 
Muller P., and Pénin, J., 2006, Why do firms disclose knowledge and how does it matter? Journal of Evolutionary Economics, 16, 85-108.

Noel, M.D., and Schankermann, M.A., 2006, Strategic Patenting and Software Innovation. The Journal of Industrial Organization, 61,481-520.

Orsenigo, L, and Sterzi, V., 2010, Comparative study if the use of patents in different industries. KITeS Working Paper, $\mathrm{n}^{\circ} 33$.

Oslon, K., 2004, Firm Characteristics and the Speed of FDA Approval. Journal of Economics and Management, 6, 377-401.

Paul, S.M., Mytelka, D.S., Dunwiddie, C.T., Persinger C.C., Munos, B.H., Lindborg, S.R. and Schach, AL., 2010, How to improve R\&D productivity: the pharmaceutical industry's grand challenge. Nature Reviews Drug Discovery, 9, 203-214.

Pisano, G.P., 2006, Can science be a business? Lessons from biotech. Harvard Business Review, 84, 114124.

Rzakhanov, Z., 2008, Regulatory policy, value of knowledge assets and innovation strategy: The case of the Orphan Drug Act. Research Policy, 37, 673-689.

Rinaldi, A., 2005, Adopting an orphan. EMBO Report, 6, 507- 510.

Ritter, J.R., 1984, Signaling and the valuation of unseasoned new issues: A comment. Journal of Finance, 39, 1231-1237.

Ritter, J.R., and Welch I., 2002, A Review of IPO Activity, Pricing, and Allocations. Journal of Finance, 57, 1795-1828.

Seoane-Vazquez, E., Rodriguez-Monguio, R., Szeinbach, S.L., and Visaria, J., 2008, Incentives for orphan drug research and development in the United States. Orphanet Journal of Rare Disease, 3, 33-39.

Shulman, S.R., and Manocchia, M., 1997, The U.S. orphan drug program 1983-1995. PharmacoEconomics, 12, 312-26.

Spence, M., 1973, Job Market Signaling. Quarterly Journal of Economics, 87, 355-374.

Stuart, T., Hoang, H., and Hybels, R.G., 1999, Interorganizational endorsement and the performance of entrepreneurial ventures. Administrative Science Quarterly, 44, 315-349.

Trajtenberg, M., 1990, A penny for your quotes: patent citations and the value of innovations. The Rand Journal of Economics, 21, 172-187.

Useche, D., 2014, Are patents signals for the IPO market? An EU-US comparison for the software industry. Research Policy, 43, 1299-2014.

Wilbon, A.D., 1999, An empirical investigation of technology strategy in computer software initial public offering firms. Journal of Engineering and Technology Management, 16, 147-169.

Windmeijer, F. 2005. A finite sample correction for the variance of linear efficient two-step GMM estimators. Journal of Econometrics 126: 25-51.

Yin, W., 2008, Market incentives and pharmaceutical innovation. Journal of Health Economics 27 : 10601077. 
Figure 1. FDA registration of OD designations from 1983 to 2015.

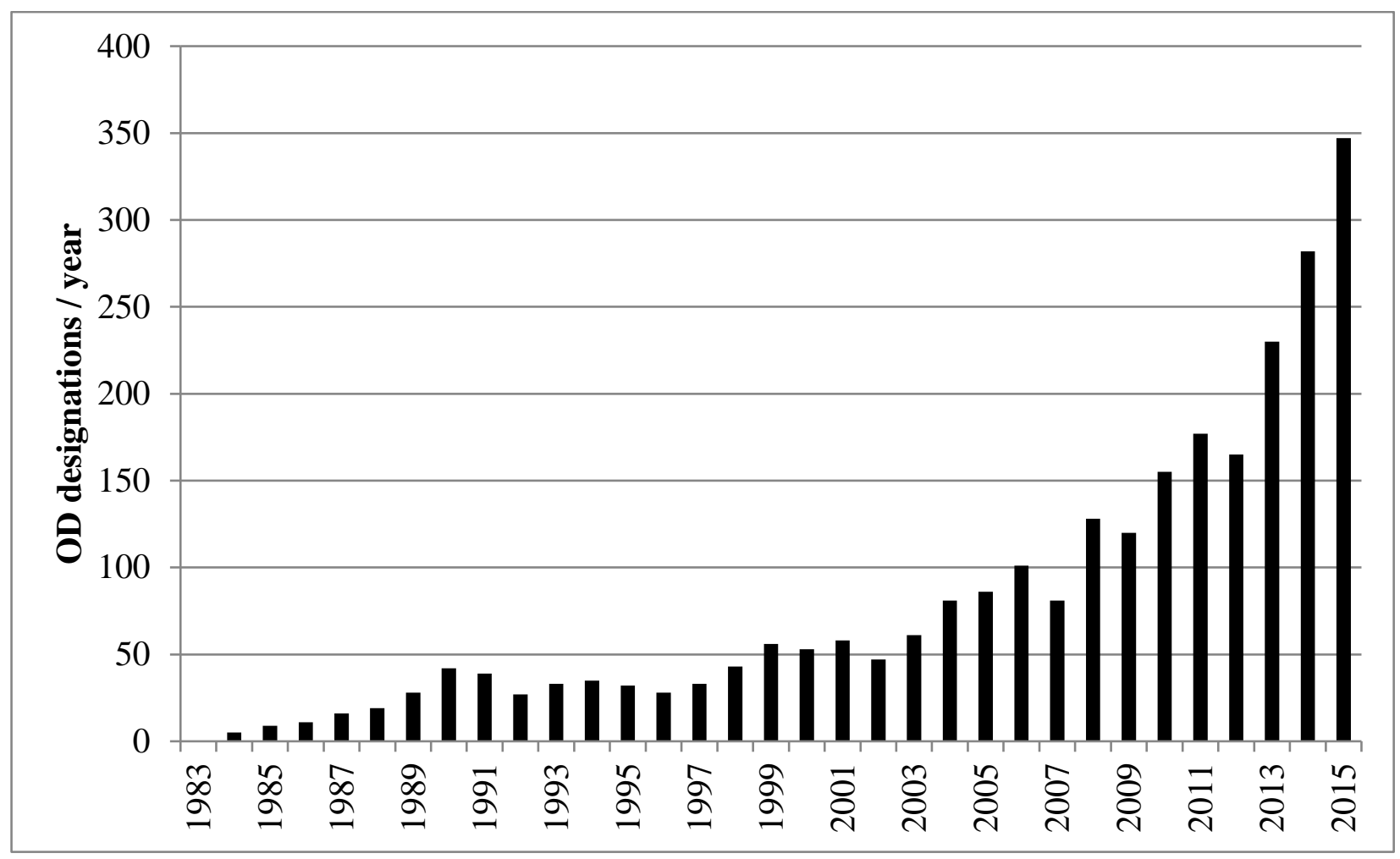


Figure 2. Trends of OD firms IPO.

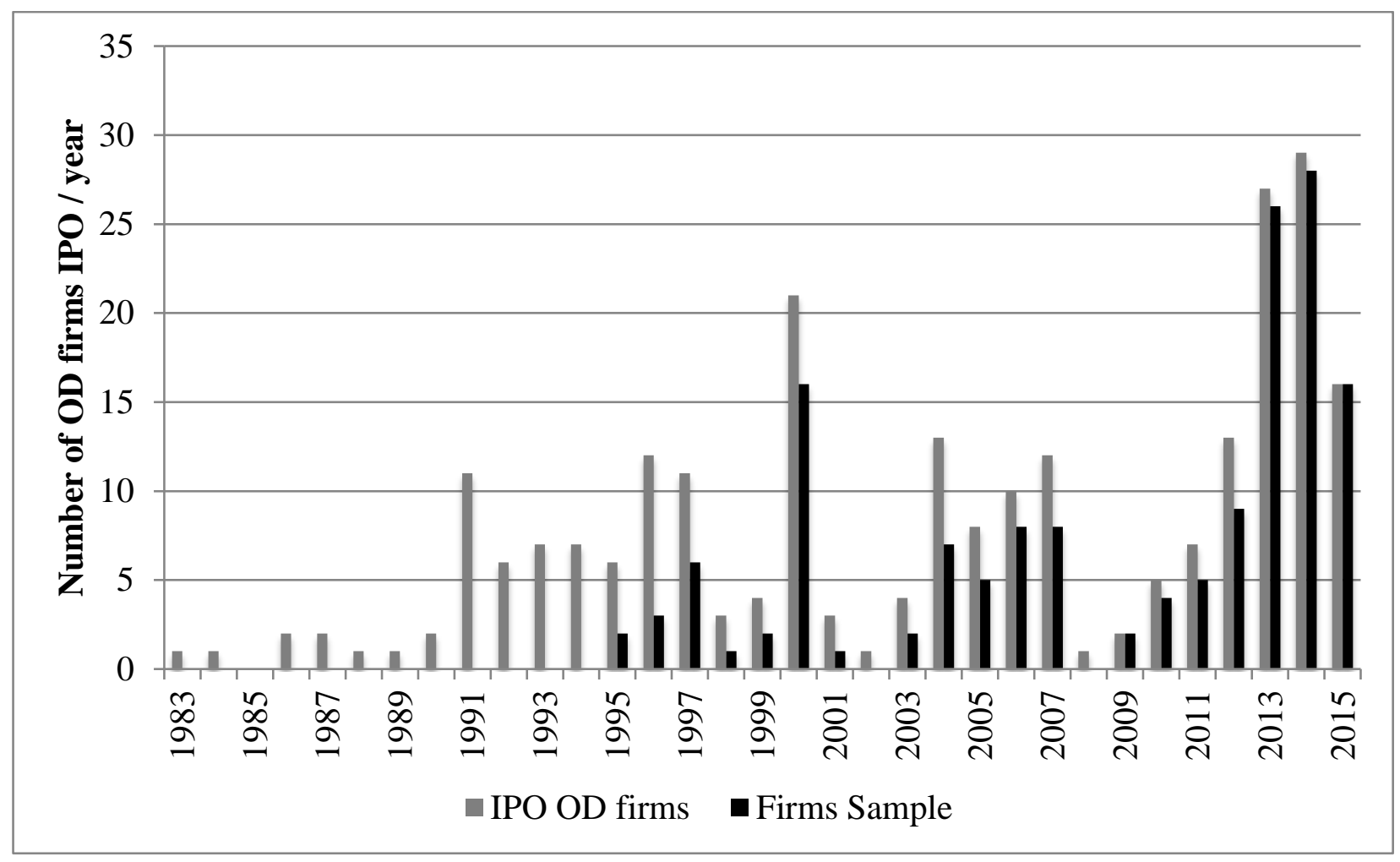


Table 1. SIC code distribution of OD firms IPO sample

\begin{tabular}{lcl}
\hline SIC & Number of firms & \multicolumn{1}{c}{ Description } \\
\hline 2833 & 1 & Medicinal chemicals and botanical products \\
2834 & 108 & Pharmaceuticals preparation \\
2836 & 26 & Biological products, except diagnostic substances \\
3841 & 1 & Surgical \& medical instruments \& apparatus \\
8731 & 10 & Services-commercial physical \& biological research \\
\hline Total & $\mathbf{1 4 6}$ & \\
\hline
\end{tabular}


Table 2. Variable description and summary statistics

\begin{tabular}{|c|c|c|c|c|c|}
\hline \multirow[t]{2}{*}{ Variable code } & \multicolumn{3}{|c|}{ OD firms } & \multirow[t]{2}{*}{ Definition } & \multirow[t]{2}{*}{ Source } \\
\hline & Mean & Min & Max & & \\
\hline \multicolumn{6}{|l|}{ Dependent variables } \\
\hline LOG (PROCEEDS) & 17,581 & 10,878 & 19,209 & Logarithm of amount collected at IPO. & IPO prospectus \\
\hline \multicolumn{6}{|l|}{ Independent variables } \\
\hline ODD & 0,863 & 0 & 6 & Number of Orphan drug designations applied by the firm at date of IPO & OD database \\
\hline \multicolumn{6}{|l|}{ Controls } \\
\hline PATAPPУ 4 & 15,137 & 0 & 328 & Number of patents applied for by the firm in last four years prior to IPO & Q-Qpad \\
\hline PHASE2PRIORIPO & 1,116 & 0 & 7 & Number of Drugs in at least Phase II in the Pipeline prior to IPO & Pharma Project \\
\hline LOG (R\&D_EXPENSES) & 15,867 & 11,820 & 18,266 & Logarithm of Research and Development expenses in year prior to IPO & IPO prospectus \\
\hline AGE AT IPO & 8,390 & 2 & 23 & Age of company at IPO & IPO prospectus \\
\hline EMPLOYEES & 59,007 & 0 & 470 & Number of employees at date of IPO & IPO prospectus \\
\hline LOG (REVENUES+1) & 7,713 & 0 & 18,688 & Logarithm of the total revenues in year prior to IPO & IPO prospectus \\
\hline SICSEC2834 & 0,726 & 0 & 1 & DV recorded a value of 1 if company's principal segment is SIC 2834, 0 otherwise & IPO prospectus \\
\hline LOG (PERCENT SOLD) & $-1,388$ & $-4,529$ & 0 & Logarithm of percentage of firm to be sold during a public equity offering & IPO prospectus \\
\hline UWREPUT & 0,041 & 0 & 1 & The prestige of the IPO firm's lead underwriter & $\begin{array}{c}\text { Ritter ranking } \\
\text { Venture }\end{array}$ \\
\hline VENTURE BACKED & 0,733 & 0 & 1 & DV recorded a value of 1 if company is a venture capital-backed IPO, 0 otherwise & $\begin{array}{l}\text { Source } \\
\text { Venture }\end{array}$ \\
\hline CORPVCAP & 0,178 & 0 & 1 & DV recorded a value of 1 if company is a corporate venture-backed IPO, 0 otherwise & Source \\
\hline NASDAQ & 0,973 & 0 & 1 & DV recorded a value of 1 if company was quoted on NASDAQ (US) & IPO prospectus \\
\hline BIO_RATIO & 0,208 & 0,023 & 0,357 & Ratio of Biotech IPOs divided by total number of IPOs in a given year & Capital IQ \\
\hline$B U B B L E$ & 0,123 & 0 & 1 & DV recorded a value of 1 if company was quoted on 1999 or 2000 & IPO prospectus \\
\hline ODD-Lagged & 0,438 & 0 & 6 & Four years lagged number of Orphan drug designations applied by the firm & OD database \\
\hline ODEXPERIENCE & 2,840 & 0 & 22,838 & Number of years from the first Orphan Drug Designation to IPO & OD database \\
\hline LAUNCHPRIORIPO & 0,425 & 0 & 18 & Number of Drugs launched in the Pipeline prior to IPO & Pharma Project \\
\hline LICENSINGPRIORIPO & 1,683 & 0 & 14 & Number of Drugs under license in the Pipeline prior to IPO & Pharma Project \\
\hline
\end{tabular}


Table 3. Pearson Correlation matrix

\begin{tabular}{|c|c|c|c|c|c|c|c|c|c|c|}
\hline & & 1 & 2 & 3 & 4 & 5 & 6 & 7 & 8 & 9 \\
\hline 1 & LOG (PROCEEDS) & 1.0000 & & & & & & & & \\
\hline 2 & $O D D$ & 0.1146 & 1.0000 & & & & & & & \\
\hline 3 & РАТАРРУ 4 & 0.1106 & 0.1439 & 1.0000 & & & & & & \\
\hline 4 & PHASE2PRIORIPO & 0.0750 & 0.1367 & 0.0987 & 1.0000 & & & & & \\
\hline 5 & LOG (R\&D_EXPENSES) & $0.4119 *$ & -0.0164 & 0.2362 & 0.1462 & 1.0000 & & & & \\
\hline 6 & AGE AT IPO & -0.1553 & $0.3585^{*}$ & 0.3008 & 0.1940 & 0.0668 & 1.0000 & & & \\
\hline 7 & EMPLOYEES & 0.2138 & 0.1235 & $0.3905^{*}$ & 0.2513 & $0.4213^{*}$ & 0.1862 & 1.0000 & & \\
\hline 8 & LOG (REVENUES+1) & 0.0561 & 0.0635 & 0.2161 & 0.0497 & 0.2874 & 0.2184 & $0.4542 *$ & 1.0000 & \\
\hline 9 & SICSEC2834 & 0.1943 & -0.1101 & 0.1211 & 0.0208 & 0.1785 & -0.0797 & 0.0826 & 0.0156 & 1.0000 \\
\hline 10 & LOG (PERCENT SOLD) & 0.1154 & -0.0004 & -0.0489 & 0.0369 & -0.0523 & 0.0232 & -0.1138 & -0.1023 & 0.0740 \\
\hline 11 & UWREPUT & 0.1356 & -0.0829 & 0.1086 & 0.0085 & 0.1075 & 0.0180 & 0.2441 & 0.0944 & -0.0276 \\
\hline 12 & VENTURE BACKED & 0.3124 & -0.0040 & 0.0114 & -0.1575 & $0.3580^{*}$ & -0.0267 & -0.0245 & 0.0465 & 0.1845 \\
\hline 13 & CORPVCAP & 0.1015 & 0.1159 & 0.0974 & 0.0142 & 0.1718 & 0.1263 & 0.0782 & 0.1593 & 0.0049 \\
\hline 14 & NASDAQ & 0.1593 & -0.0174 & 0.0799 & -0.2238 & 0.1639 & -0.0779 & -0.1682 & -0.0032 & 0.1791 \\
\hline 15 & BIO_RATIO & 0.1194 & 0.1334 & 0.0498 & 0.1398 & -0.0183 & 0.2582 & -0.1644 & -0.1498 & -0.0044 \\
\hline 16 & $B U B B L E$ & 0.1138 & -0.0872 & 0.0004 & 0.0154 & 0.0190 & -0.1845 & 0.1071 & 0.0991 & -0.0499 \\
\hline 17 & ODD-Four_year_lagged & 0.0521 & $0.8231^{*}$ & 0.1764 & 0.0538 & -0.1063 & $0.3406^{*}$ & 0.1142 & 0.1104 & 0.0083 \\
\hline 18 & ODEXPERIENCE & 0.1072 & $0.6552 *$ & 0.0706 & 0.1159 & 0.0236 & 0.2783 & 0.1074 & -0.0053 & 0.0293 \\
\hline 19 & LAUNCHPRIORIPO & 0.0507 & $0.3973 *$ & -0.0270 & -0.0809 & 0.0041 & -0.0315 & 0.1501 & 0.1077 & 0.0732 \\
\hline \multirow[t]{2}{*}{20} & LICENSINGPRIORIPO & 0.1247 & 0.2724 & 0.0025 & $0.3558 *$ & 0.1342 & 0.0146 & 0.2992 & 0.1909 & -0.0953 \\
\hline & & 10 & 11 & 12 & 13 & 14 & 15 & 16 & 17 & 18 \\
\hline 11 & UWREPUT & 1.0000 & & & & & & & & \\
\hline 12 & VENTURE BACKED & 0.1250 & 1.0000 & & & & & & & \\
\hline 13 & CORPVCAP & 0.0840 & 0.2810 & 1.0000 & & & & & & \\
\hline 14 & NASDAQ & 0.0347 & 0.0883 & 0.0781 & 1.0000 & & & & & \\
\hline 15 & BIO_RATIO & 0.0829 & 0.0790 & -0.0261 & 0.0065 & 1.0000 & & & & \\
\hline 16 & $B U B B L E$ & 0.0273 & -0.0561 & 0.0433 & 0.0629 & -0.2547 & 1.0000 & & & \\
\hline 17 & ODD-Lagged & -0.0914 & 0.0171 & 0.0650 & 0.0318 & 0.0940 & -0.1026 & 1.0000 & & \\
\hline 18 & ODEXPERIENCE & -0.1052 & 0.0142 & -0.0016 & -0.0057 & 0.0679 & -0.1207 & $0.6836^{*}$ & 1.0000 & \\
\hline 19 & LAUNCHPRIORIPO & -0.0319 & 0.0144 & -0.0753 & 0.0175 & -0.0856 & -0.0453 & $0.5470 *$ & $0.4115^{*}$ & 1.0000 \\
\hline 20 & LICENSINGPRIORIPO & 0.0116 & -0.0597 & 0.0349 & -0.1755 & -0.0324 & 0.1216 & 0.2929 & 0.2747 & $0.3897 *$ \\
\hline
\end{tabular}


GORRY-USECHE NBER PPMf2017

Table 4. The value of OD designations for IPO investors

\begin{tabular}{|c|c|c|}
\hline & $\begin{array}{c}1 \\
\text { OLS } \\
L O G(P R O C E E D S) \\
\end{array}$ & $\begin{array}{c}2 \\
\text { GMM } \\
L O G(P R O C E E D S) \\
\end{array}$ \\
\hline$O D D$ & $\begin{array}{l}0.183^{* *} \\
(0.0747)\end{array}$ & $\begin{array}{l}0.173^{* *} \\
(0.0809)\end{array}$ \\
\hline РАТАРРУ 4 & $\begin{array}{l}0.000900 \\
(0.00149)\end{array}$ & $\begin{array}{l}0.000913 \\
(0.00301)\end{array}$ \\
\hline PHASE2PRIORIPO & $\begin{array}{c}0.0266 \\
(0.0678)\end{array}$ & $\begin{array}{c}0.0275 \\
(0.0729)\end{array}$ \\
\hline LOG (R\&D_EXPENSES) & $\begin{array}{c}0.297 * * * \\
(0.0718)\end{array}$ & $\begin{array}{c}0.295 * * * \\
(0.0877)\end{array}$ \\
\hline AGE AT IPO & $\begin{array}{c}-0.0693^{* *} \\
(0.0337)\end{array}$ & $\begin{array}{c}-0.0685^{* * *} \\
(0.0190)\end{array}$ \\
\hline EMPLOYEES & $\begin{array}{c}0.00281^{* *} \\
(0.00127)\end{array}$ & $\begin{array}{c}0.00285 \\
(0.00179)\end{array}$ \\
\hline LOG (REVENUES+1) & $\begin{array}{l}-0.00501 \\
(0.0125)\end{array}$ & $\begin{array}{c}-0.00509 \\
(0.0120)\end{array}$ \\
\hline SICSEC2834 & $\begin{array}{c}0.223 \\
(0.272)\end{array}$ & $\begin{array}{c}0.219 \\
(0.191)\end{array}$ \\
\hline LOG (PERCENT SOLD) & $\begin{array}{c}0.309 \\
(0.223)\end{array}$ & $\begin{array}{l}0.308^{* *} \\
(0.157)\end{array}$ \\
\hline UWREPUT & $\begin{array}{c}0.311^{* *} \\
(0.138)\end{array}$ & $\begin{array}{c}0.302 \\
(0.430)\end{array}$ \\
\hline VENTURE BACKED & $\begin{array}{l}0.467 * \\
(0.242)\end{array}$ & $\begin{array}{c}0.469^{* *} \\
(0.214)\end{array}$ \\
\hline CORPVCAP & $\begin{array}{l}-0.0175 \\
(0.186)\end{array}$ & $\begin{array}{l}-0.0147 \\
(0.223)\end{array}$ \\
\hline NASDAQ & $\begin{array}{c}0.421 \\
(0.311)\end{array}$ & $\begin{array}{c}0.428 \\
(0.556)\end{array}$ \\
\hline BIO_RATIO & $\begin{array}{c}2.160^{* *} \\
(0.945)\end{array}$ & $\begin{array}{c}2.168^{* * *} \\
(0.815)\end{array}$ \\
\hline$B U B B L E$ & $\begin{array}{c}0.482 * * * \\
(0.173)\end{array}$ & $\begin{array}{l}0.481^{*} \\
(0.257)\end{array}$ \\
\hline Constant & $\begin{array}{c}12.13^{* * *} \\
(0.946) \\
\end{array}$ & $\begin{array}{c}12.14^{* * *} \\
(1.285) \\
\end{array}$ \\
\hline Observations & 146 & 146 \\
\hline Adjusted_R-squared & 0.289 & 0.289 \\
\hline Sargan-Hansen test & & $0.501(\mathrm{p}=0.479)$ \\
\hline First stage F-statistic & & $130.7 * * *$ \\
\hline Anderson canon. corr. LM statistic & & $97.76^{* * *}$ \\
\hline Wu-Husman test & & $0.049(\mathrm{p}=0.8259)$ \\
\hline
\end{tabular}

Robust standard errors in parentheses.

${ }^{*} \mathrm{p}<0.1,{ }^{* *} \mathrm{p}<0.05,{ }^{* * *} \mathrm{p}<0.01$ 
Table 5. Alternative specifications with OLS and IV approach

\begin{tabular}{|c|c|c|c|c|c|c|}
\hline VARIABLES & $\begin{array}{c}3 \\
\text { OLS1 } \\
\end{array}$ & $\begin{array}{c}4 \\
\text { OLS2 } \\
\end{array}$ & $\begin{array}{c}5 \\
\text { OLS3 } \\
\end{array}$ & $\begin{array}{c}6 \\
\text { LIML1 }\end{array}$ & $\begin{array}{c}7 \\
\text { LIML2 }\end{array}$ & $\begin{array}{c}8 \\
\text { LIML3 }\end{array}$ \\
\hline \multirow[t]{2}{*}{$O D D$} & $0.190^{* *}$ & $0.188^{* *}$ & $0.189^{* *}$ & $0.181^{* *}$ & $0.176^{* *}$ & $0.179^{* *}$ \\
\hline & $(0.0800)$ & $(0.0794)$ & $(0.0794)$ & $(0.0845)$ & $(0.0845)$ & $(0.0842)$ \\
\hline \multirow[t]{2}{*}{ РАТАРРУ 4} & 0.000743 & 0.000750 & 0.000719 & 0.000767 & 0.000781 & 0.000744 \\
\hline & $(0.00165)$ & $(0.00164)$ & $(0.00164)$ & $(0.00304)$ & $(0.00303)$ & $(0.00303)$ \\
\hline \multirow[t]{2}{*}{ DRUG_PIPEPRIORIPO } & -0.00247 & -0.00259 & & -0.00220 & -0.00225 & \\
\hline & $(0.0117)$ & $(0.0117)$ & & $(0.00789)$ & $(0.00787)$ & \\
\hline \multirow[t]{2}{*}{ LOG (R\&D_EXPENSES) } & $0.306^{* * *}$ & $0.296^{* * *}$ & $0.287 * * *$ & $0.304 * * *$ & $0.294 * * *$ & $0.286^{* * *}$ \\
\hline & $(0.0731)$ & $(0.0738)$ & $(0.0766)$ & $\begin{array}{c}(0.0868) \\
-\end{array}$ & $\begin{array}{c}(0.0878) \\
-\end{array}$ & $\begin{array}{c}(0.0890) \\
-\end{array}$ \\
\hline \multirow[t]{2}{*}{ AGE AT IPO } & $-0.0680 * *$ & $-0.0682 * *$ & $-0.0687 * *$ & $0.0674 * * *$ & $0.0674 * * *$ & $0.0681^{* * *}$ \\
\hline & $(0.0335)$ & $(0.0332)$ & $(0.0335)$ & $(0.0191)$ & $(0.0190)$ & $(0.0190)$ \\
\hline \multirow[t]{2}{*}{ EMPLOYEES } & $0.00296 * *$ & $0.00300^{* *}$ & $0.00292 * *$ & $0.00299 *$ & $0.00304 *$ & $0.00295 *$ \\
\hline & $(0.00135)$ & $(0.00136)$ & $(0.00139)$ & $(0.00179)$ & $(0.00179)$ & $(0.00179)$ \\
\hline \multirow[t]{2}{*}{ LOG (REVENUES+1) } & -0.00541 & -0.00547 & -0.00505 & -0.00548 & -0.00555 & -0.00512 \\
\hline & $(0.0124)$ & $(0.0124)$ & $(0.0125)$ & $(0.0120)$ & $(0.0119)$ & $(0.0120)$ \\
\hline \multirow[t]{2}{*}{ SICSEC2834 } & 0.231 & 0.227 & 0.220 & 0.228 & 0.223 & 0.216 \\
\hline & $(0.272)$ & $(0.270)$ & $(0.269)$ & $(0.190)$ & $(0.190)$ & $(0.191)$ \\
\hline \multirow[t]{2}{*}{ LOG (PERCENT SOLD) } & 0.316 & 0.317 & 0.307 & $0.315^{* *}$ & $0.316^{* *}$ & $0.307^{* *}$ \\
\hline & $(0.221)$ & $(0.221)$ & $(0.223)$ & $(0.156)$ & $(0.156)$ & $(0.156)$ \\
\hline \multirow[t]{2}{*}{ UWREPUT } & $0.302^{* *}$ & $0.289 *$ & $0.288 *$ & 0.294 & 0.278 & 0.280 \\
\hline & $(0.149)$ & $(0.149)$ & $(0.148)$ & $(0.431)$ & $(0.430)$ & $(0.430)$ \\
\hline \multirow[t]{2}{*}{ VENTURE BACKED } & $0.448 *$ & & & $0.449^{* *}$ & & \\
\hline & $(0.258)$ & & & $(0.208)$ & & \\
\hline \multirow[t]{2}{*}{ CORPVCAP } & -0.0156 & -0.0201 & -0.0276 & -0.0128 & -0.0165 & -0.0248 \\
\hline & $(0.190)$ & $(0.185)$ & $(0.184)$ & $(0.223)$ & $(0.222)$ & $(0.222)$ \\
\hline \multirow[t]{2}{*}{ NASDAQ } & 0.362 & 0.357 & 0.429 & 0.368 & 0.366 & 0.435 \\
\hline & $(0.298)$ & $(0.298)$ & $(0.311)$ & $(0.541)$ & $(0.540)$ & $(0.554)$ \\
\hline \multirow[t]{2}{*}{ BIO_RATIO } & $2.203^{* *}$ & $2.181^{* *}$ & $2.094^{* *}$ & $2.212 * * *$ & $2.193 * * *$ & $2.104^{* *}$ \\
\hline & $(1.025)$ & $(1.024)$ & $(0.992)$ & $(0.804)$ & $(0.804)$ & $(0.817)$ \\
\hline \multirow[t]{2}{*}{ BUBBLE } & $0.498 * * *$ & $0.503^{* * *}$ & $0.495^{* * *}$ & $0.496^{*}$ & $0.501^{*}$ & $0.493 *$ \\
\hline & $(0.172)$ & $(0.174)$ & $(0.177)$ & $(0.258)$ & $(0.257)$ & $(0.257)$ \\
\hline \multirow[t]{2}{*}{ LOG(VCFUNDS+1) } & & $0.0264 *$ & $0.0281^{* *}$ & & $0.0266^{* *}$ & $0.0282^{* *}$ \\
\hline & & $(0.0139)$ & $(0.0135)$ & & $(0.0117)$ & $(0.0120)$ \\
\hline PHASE2PRIORIPO & & & $\begin{array}{c}0.0395 \\
(0.0541)\end{array}$ & & & $\begin{array}{c}0.0397 \\
(0.0753)\end{array}$ \\
\hline \multirow[t]{2}{*}{ OTHER_DRUG_PIPELINE } & & & -0.00425 & & & -0.00398 \\
\hline & & & $(0.0112)$ & & & $(0.00840)$ \\
\hline Constant & $\begin{array}{c}12.08^{* * *} \\
(0.990)\end{array}$ & $\begin{array}{c}12.23^{* * *} \\
(0.989)\end{array}$ & $\begin{array}{c}12.26 * * * \\
(1.000)\end{array}$ & $\begin{array}{c}12.09 * * * \\
(1.288)\end{array}$ & $\begin{array}{c}12.26^{* * *} \\
(1.300)\end{array}$ & $\begin{array}{c}12.28 * * * \\
(1.300)\end{array}$ \\
\hline Observations & 146 & 146 & 146 & 146 & 146 & 146 \\
\hline Adjusted_R-squared & 0.363 & 0.365 & 0.366 & 0.363 & 0.365 & 0.366 \\
\hline
\end{tabular}

Robust standard errors in parentheses.

${ }^{*} \mathrm{p}<0.1,{ }^{* *} \mathrm{p}<0.05,{ }^{* * *} \mathrm{p}<0.01$ 